\title{
International Linkages of the Indian Commodity Futures Markets
}

\author{
Brajesh Kumar ${ }^{1}$, Ajay Pandey ${ }^{2}$ \\ ${ }^{1}$ Jindal Global Business School, O P Jindal Global University, New Delhi, India \\ ${ }^{2}$ Finance and Accounting Area, Indian Institute of Management Ahmedabad, Ahmedabad, India \\ E-mail:bkumar@jgu.edu.in,apandey@iimahd.ernet.in \\ Received January 6, 2011; revised March 2, 2011; accepted March 22, 2011
}

\begin{abstract}
This paper investigates the cross market linkages of Indian commodity futures for nine commodities with futures markets outside India. These commodities range from highly tradable commodities to less tradable agricultural commodities. We analyze the cross market linkages in terms of return and volatility spillovers. The nine commodities consist of two agricultural commodities: Soybean, and Corn, three metals: Aluminum, Copper and Zinc, two precious metals: Gold and Silver, and two energy commodities: Crude oil and Natural gas. Return spillover is investigated through Johansen's cointegration test, error correction model, Granger causality test and variance decomposition techniques. We apply Bivariate GARCH model (BEKK) to investtigate volatility spillover between India and other World markets. We find that futures prices of agricultural commodities traded at National Commodity Derivatives Exchange, India (NCDEX) and Chicago Board of Trade (CBOT), prices of precious metals traded at Multi Commodity Exchange, India (MCX) and NYMEX, prices of industrial metals traded at MCX and the London Metal Exchange (LME) and prices of energy commodities traded at MCX and NYMEX are cointegrated. In case of commodities, it is found that world markets have bigger (unidirectional) impact on Indian markets. In bivariate model, we found bi-directional return spillover between MCX and LME markets. However, effect of LME on MCX is stronger than the effect of MCX on LME. Results of return and volatility spillovers indicate that the Indian commodity futures markets function as a satellite market and assimilate information from the world market.
\end{abstract}

Keywords: International Linkages, Commodity Futures Markets, Return Spillover, Volatility Spillover, Variance Decomposition Techniques, BEKK

\section{Introduction}

Risk management and price discovery are two of the most important functions of futures market [1-2]. Futures markets perform risk allocation function whereby futures contracts can be used to lock-in prices instead of relying on uncertain spot price movements. Price discovery is the process by which information is assimilated in a market and price converges towards the efficient price of the underlying asset. In financial economic literature, the price discovery function of futures market has been studied in two broad contexts a) return and volatility spillover between spot and futures of an asset, and b) international link-ages or return and volatility spillover across different futures markets (across countries). This paper focuses on the latter, studying the return and volatility spillover between Indian and international commodity futures markets. Another interesting prospective on understanding market linkages has its origin in the efficient market hypothesis which says that all markets incorporate any new information simultaneously and there does not exist any lead-lag relationship across these markets. However, frictions in markets, in terms of transaction costs and information asymmetry, may lead to return and volatility spillovers between markets. Moreover, all the markets do not trade simultaneously for many assets and commodeties. Besides being of academic interest, understanding information flow across markets is also important for hedge funds, portfolio managers and hedgers for hedging and devising cross-market investment strategies. 
Empirical literature on price discovery in futures markets mostly covers the relationship between futures and underlying spot prices. In equity markets, price discovery function of futures markets has been extensively studied [3-11]. In commodity futures market, price discovery function of futures markets has also been investigated [12-16]. However, these studies are mostly from developed markets like US and UK. Most of the studies in equity and commodity spot-futures markets linkages confirm the leading role of futures markets in information transmission and in fore- casting future spot prices. Surprisingly, very few studies have sought to investigate the information transmission through futures prices on the same underlying, traded across different markets. In emerging commodity futures market context, international linkages of commodity futures market with developed futures markets have been even less explored.

Since the inception of the organized commodity derivatives markets in India in 2003, Indian futures markets have grown rapidly. In 2003, three national level multi commodity exchanges, National Multi Commodity Exchange (NMCE), Multi Commodity Exchange (MCX) and National Commodities and Derivatives Exchange (NCDEX), were setup. At present, commodity futures are traded on three national exchanges, and 20 other regional exchanges, which have been in existence for longer time. Currently, the futures contracts of around 103 commodities are traded on three national exchanges. In terms of volume, Copper, Gold, Silver and Crude futures traded on Multi Commodity Exchange (MCX), India has been ranked within the top 10 most actively traded futures contracts ${ }^{1}$ in the world. However, the commodity futures markets in India are subject to many regulations and many a times have been criticized for speculative trading activity as well as for causing an increase in spot price volatility [17]. Emerging commodity markets are generally criticized for speculative activity and destabilizing role of derivatives on spot market through increased price volatility $[16,18,19]$.

Most of the studies on Indian commodity futures markets are limited to policy related issues. Some of the major issues identified and investigated in Indian commodity futures are: the role of spot markets integration and friction (high transaction cost), proper contract design, identification of delivery location, importance of warehousing facilities and policy issues like restriction on cross-border movement of commodities, different kind of taxes etc [20-22]. The literature on price discovery on

${ }^{1}$ Leading commodity futures contracts in terms of volume are Gold, Crude, Natural gas, and Silver futures traded at NYMEX in US, Aluminum, Copper, and Zinc futures traded at LME, London, and Corn, Soybean contracts at CBOT in US. (Details:

http://www.futuresindustry.org/files/pdf/Jul-Aug_FIM/Jul-Aug_Volum e.pdf)
Indian com- modity futures markets is limited to regional exchanges, dated/small sample form the period prior to setting up of national exchanges, or to very fewer commodities traded on national exchanges [23-26]. The Indian commodity futures markets have since then matured and have started playing a significant role in price discovery and risk management in the recent period, if increased volume of trading is any indicator. Trade and financial liberalization in the country and rest of the world may also have led to strong integration of Indian markets with their world counterparts. However, the relationship between the Indian and world commod- ity futures markets has not been explored adequately and hence there is a case for investigating the linkages of Indian commodity futures markets with the counterparts elsewhere in the world trading the futures contracts on the same underlying.

\section{Literature Review}

The research on international linkages across markets has been mainly on the financial asset markets [27-34]. Eun and Shim [23] found the dominance of US equity market in information dissemination to rest of the world. They found that any innovations in the US equity futures market are rapidly transmitted to other markets, whereas no single foreign market can significantly explain US market movements. Koutmos and Booth [30] investigated the dynamic interaction across three major stock markets New York (S\&P 500), London (FTSE 100) and Tokyo (Nikkie 225) and found significant price spillovers from New York to London and Tokyo and from Tokyo to London market. Susmel and Engle [29] investigated the return and volatility spillovers between US and UK equity markets but did not find strong evidence of return and volatility spillovers between these two while the studies cited above examined cross-market linkage where the underlying differed. Tse [23] investigated the Eurodollar futures markets in Chicago, Singapore, and London and found that all these markets are cointegrated by a common factor. Booth et al. [31] found that Nikkei 225 Index futures that are traded in Singapore, London and Chicago are cointegrated.

In commodity futures context, Booth and Ciner [35] investigated the return and volatility spillovers of corn futures between the CBOT and the Tokyo Grain Exchange (TGE). They found significant return and volatility spillovers between the two markets. Booth, Brockman, and Tse [33] studied the wheat futures traded on the Chicago Board of Trade (CBOT) of US and the Winnipeg Commodities Exchange (WCE) of Canada and found one way information spillover from CBOT to WCE. Low, Muthuswamy, and Webb [36] examined the futures 
prices for storable commodities, soybeans and sugar, which are traded on the TGE and the Manila International Futures Exchange (MIFE), and found no co-integration between these two markets. Lin and Tamvakis [37] examined the information transmission mechanism and price discovery process in crude oil and refined oil products traded on the New York Mercantile Exchange (NYMEX); and London's International Petroleum Exchange (IPE). They found substantial spillover effects between two markets where IPE morning prices seem to be considerably affected by the closing price of the previous day on NYMEX. Holder, Pace and Tomas III [38] investigated the market linkage between US and Japan for Corn and Soybean futures. They considered Corn and Soybean futures traded on the Chicago Board of Trade (CBOT) in US and the Tokyo Grain Exchange (TGE), and the Kanmon Commodity Exchange (KCE) in Japan. They found that trading at CBOT had very little effect on the Japanese contract volumes. Xu and Fung [39] investigated the crossmarket linkages between US and Japan for precious metals futures: Gold, platinum, and Silver. They applied bivariate asymmetric ARMA-GARCH model to estimate the return and volatility spillovers between these two markets and found that there was a strong linkage between these markets with US market playing a leading role in return spillover. They, however, found bidirec- tional volatility spillover between the two markets. Kao and Wan [40] studied the price discovery process in spot and futures markets for Natural gas in the US and UK using a quadvariate VAR model. They found that all spot prices and futures prices were driven by one common factor. They found that the US futures market dominated over UK futures market and acted as the center for price discovery. They also concluded that the spot markets in the US and UK were less efficient than their corresponding futures market.

In the emerging markets context, Fung, Leung and $\mathrm{Xu}$ [41] examined the information spillover between US futures markets and the emerging commodity futures market in China for three commodity futures: Copper, Soybean, and Wheat. They used VECM-GARCH model and found that for Copper and Soybean, US futures market played a dominant role in transmitting information to the Chinese market. However, in the case of Wheat, which is highly regulated and subsidized in China, both markets were highly segmented. Hua and Chen [42] investigated the international linkages of Chinese commodity futures markets. Commodities considered in the analysis were: Aluminium, Copper, Soybean and Wheat. Aluminum and Copper futures traded on LME and Soybean and Wheat futures traded on CBOT were analyzed. They applied Johansen's cointegration test, error correction model, and Granger causal- ity test and impulse response analyses to understand the relationship. They found that Aluminum, Copper and Soybean futures prices are integrated with spot prices but did not find such cointegration for wheat spot and futures prices. They concluded that LME had a bigger impact on Shanghai Copper and Aluminium futures and CBOT had a bigger impact on Dalian Soybean futures. Ge, Wang and Ahn [43] investigated the linkages between Chinese and US cotton futures market. They considered the futures prices of contracts trading on New York Board of Trade (NYBOT) in US and the Zhengzhou Commodity Exchange (CZCE) in China. They found that these markets were cointegrated and that there was bidirectional causality in returns between these markets.

To summarize, most studies on international linkages across futures markets of the same underlying suggest that there are stronger international market linkages in highly traded commodities as compared to relatively less traded commodities. Moreover the developed markets (in terms of volume and number of derivatives products) play dominant role in price discovery process. Given limited research on international linkages of futures markets in emerging markets, which are characterized by low liquidity, and exhibit higher price variability and poor information processing $[44,45]$, this paper is an attempt to investigate the cross-market link- ages of Indian commodity futures market with developed world futures markets for both high tradable (precious metals) and less tradable (agricultural) commodities.

In order to fill the research gap, this paper investigates the cross market linkages of Indian commodity futures market with their world counterparts. The commodities considered in our analysis range from agricultural commodities (Soybean and Corn), to industrial metals (Aluminium, Copper and Zinc), precious metals (Gold and Silver) and energy commodities (Brent Crude oil and Natural gas).We chose commodities which are highly traded (and have less tariff barriers/transportation costs) as well as more regulated and less traded agricultural commodities to understand and examine potential market linkage differences across commodities. We use Gold, Silver, Brent crude oil, and Natural gas futures contract traded on New York Mercantile Exchange (NYMEX), Aluminium Copper and Zinc futures contracts traded on the London Metals Exchange (LME), and Soybean and Corn futures contracts traded on the Chicago Board of Trade (CBOT). In agricultural commodities, India is the fifth largest producer of Soybean and Corn. In case of precious metals, industrial metals and energy commodeties, India is net importer. India's gold consumption is around $20 \%-25 \%$ of world's total gold production and it is also a dominant consumer of silver $(10 \%-15 \%)$. India is a major consumer country of crude oil after US, 
China, Japan, Germany and Russia. India is among top 20 major producers as well as consumers of Aluminium, Copper and Zinc.

Given this background, firstly we test that whether Indian commodity futures market is cointegrated with rest of the world in the long run and if so for which commodities (tradable/less tradable)? We expect that because of the importance of Indian market in the world and also due to world trade liberalization, Indian markets should be cointegrated with rest of the world for industrial metals, precious metals and energy commodities. It may be possible that prices are cointegrated in the long run but deviate in the short run. Hence, we further investigate whether there is any lead-lag relationship between Indian market and their world counterpart in terms of return spillover. Further, we examine the direction and speed of information transmission between the markets through return spillover. We also investigate whether there are any differences across commodities as far as return spillover is concerned. The information spillover or the market linkages are also examined by examining the second moment or volatility spillover across markets with the objective of investigation being similar to return spillover.

\section{Data and Time Series Characteristics of Returns}

To examine the international linkages of Indian commodity futures markets, we use data set consisting of two agricultural commodities: Soybean, and Corn, three metals: Aluminum, Copper and Zinc, two precious metals:
Gold and Silver, and two energy commodities: Crude oil and Natural gas. For agricultural commodities daily prices of near month futures contracts from NCDEX and for non-agricultural commodities daily prices of near month futures contracts traded on MCX are used. The selection of a particular Indian exchange is based on trading volume of the commodity futures contract. We chose Gold, Silver, Brent crude oil, and Natural gas futures price traded on New York Mercantile Exchange (NYMEX), Aluminium, Copper and Zinc futures contracts traded on the London Metals Exchange (LME), Soybean and Corn futures contracts traded on the Chicago Board of Trade (CBOT) as the counterpart markets for Indian futures markets. These are the leading exchanges for the respective commodity futures contracts in terms of volume traded. Details of the data period and source of data are given in Table 1.

We construct the continuous futures price series using daily closing futures prices of near month futures contracts for all commodities. For consistency, we converted all data into $\mathrm{USD}^{2} /$ unit. The Gold price is converted into USD $/ 10$ grams $^{3}$, Silver, Aluminium, Copper and Zinc into USD $/ \mathrm{kg}$ Soybean and Corn into USD $/ 100 \mathrm{~kg}$, Crude into USD/Barrel and Natural gas into USD/mmBtu. The daily futures returns are constructed from the futures price data as $\log \left(P_{\mathrm{s}, \mathrm{t}} / P_{\mathrm{s}, \mathrm{t}-1}\right)$, where $P_{\mathrm{s}, \mathrm{t}}$ is the futures price at time t. Standard unit root test is performed on log prices and returns series. The augmented Dickey-Fuller (ADF) ${ }^{4}$ indicates that the log prices for all commodities and in all markets have unit root and returns series are stationary. It indicates that the log prices follow an I(1) process, which is a prerequisite for the cointegration analysis.

Table 1. Details of Commodity, Data Period and Source.

\begin{tabular}{|c|c|c|c|c|}
\hline \multicolumn{2}{|c|}{ Commodities } & \multirow{2}{*}{$\frac{\text { Data-Period }}{9 / 1 / 2004 \text { to } 1 / 11 / 2008}$} & \multirow{2}{*}{$\begin{array}{c}\text { World Futures Market } \\
\text { CBOT, US }\end{array}$} & \multirow{2}{*}{$\begin{array}{c}\text { Indian Futures Market } \\
\text { NCDEX }\end{array}$} \\
\hline & Soy Bean & & & \\
\hline & Corn & $1 / 5 / 2005$ to $1 / 11 / 2008$ & CBOT, US & NCDEX \\
\hline \multirow{2}{*}{ Bullion } & Gold & $5 / 5 / 2005$ to $4 / 7 / 2008$ & COMEX, US & MCX \\
\hline & Silver & $5 / 5 / 2005$ to $4 / 7 / 2008$ & COMEX, US & MCX \\
\hline \multirow{3}{*}{ Metals } & Aluminium & $2 / 2 / 2006$ to $7 / 31 / 2007$ & LME, UK & MCX \\
\hline & Copper & $7 / 4 / 2005$ to $7 / 31 / 2007$ & LME, UK & MCX \\
\hline & Zinc & $8 / 1 / 2006$ to $7 / 31 / 2007$ & LME, UK & MCX \\
\hline \multirow{2}{*}{ Energy } & Crude Oil & $5 / 5 / 2005$ to $4 / 7 / 2008$ & NYMEX, US & MCX \\
\hline & Natural Gas & $8 / 7 / 2006$ to $4 / 7 / 2008$ & NYMEX, US & MCX \\
\hline
\end{tabular}

${ }^{2}$ We used the daily exchange rate to convert Indian currency Rupees into US. The exchange rate data for the required period is collected from Reserve Bank of India (Federal).

${ }^{3}$ We used the conversion factor 1 ounce $=31.1034 \mathrm{gm}$ and for Soybean, 1 Tonne $=36.744$ Bushels and for Corn, 1 Tonne $=39.368$ Bushels.

${ }^{4}$ Results of ADF test can be obtained from authors on request. 


\section{Long-Run and Short-Run Relationship in Futures Prices Traded on Indian Commodity Futures Markets and their World Counterparts}

\subsection{Johansen Cointegration Test}

As a first step to understand relationship between Indian commodity futures markets with their world counterparts, we test co-integration between Indian commodity futures market and international futures market. Cointegration theory suggests that two non-stationary series having same stochastic trend, tend to move together over the long run [46]. However, deviation from long run equilibrium can occur in the short run. The Johansen full information multivariate cointegrating procedure $[47,48]$ is widely used to perform the cointegration analy- sis. It can only be performed between the series having same degree of integration. Johansen Cointegration test can be conducted through the $k^{\text {th }}$ order vector error correc- tion model (VECM) represented as

$$
\Delta Y_{t}=\Pi Y_{t-1}+\sum_{i=1}^{k-1} \Gamma_{i} \Delta Y_{t-1}+v+\varepsilon_{t}
$$

Where, $Y_{t}$ is $(n \times 1)$ vector to be examined for cointegration, $\Delta Y_{t}=Y_{t}-Y_{t-1}, v$ is the vector of deterministic term or trend (intercept, seasonal dummies or trend), $\Pi$ and $\Gamma$ are coefficient matrix. The lag length $\mathrm{k}$ is selected on minimum value of an information criterion ${ }^{5}$. The existence of cointegration between endogenous variable is tested by examining the rank of coefficient matrix $\Pi$. If the rank of the matrix $\Pi$ is zero, no cointegration exists between the variables. If $\Pi$ is the full rank ( $n$ variables) matrix then variables in vector $Y_{t}$ are stationary. If the rank lies between zero and $p$, cointegration exists between the variables under investigation. Two likelihood ratio tests are used to test the long run relationship [44].

a) The null hypothesis of at most $r$ cointegrating vectors against a general alternative hypothesis of more than $r$ cointegrating vectors is tested by trace Statistics.

Trace statistics is given by

$$
(\lambda-\operatorname{trace})=-T \sum_{i=r+1}^{n} \ln (1-\tilde{\lambda})_{i}
$$

where $\mathrm{T}$ is the number of observations and $\lambda$ is the eigenvalues.

b) The null hypothesis of $r$ cointegrating vector against the alternative of $r+1$ is tested by Maximum Eigen value statistic

Maximum Eigen Value is given by

$$
(\lambda-\max )=-T \ln \left(1-\lambda_{r+1}\right)
$$

${ }^{5}$ We use Akaike Information Criterion (AIC) to select the lags in the cointegration equations.
In our test for the cointegration between Indian commodity futures market and their world counterpart, $n=2$ and null hypothesis would be rank $=0$ and rank $=1$. If rank $=0$ is rejected and $r=1$ is not rejected, we conclude that the two series are cointegrated. However, if rank $=0$ is not rejected, we conclude that the two series are not cointegrated.

Since all the time series of logged futures prices are I(1) series, we test the cointegration between futures prices of contracts traded in Indian commodity market and their counterpart futures exchanges elsewhere in the world. Both $\lambda_{\text {trace }}$ and $\lambda_{\max }$ statistic are used to test the cointegration. The results of the cointegration test are presented in Table 2. It is found that all commodities traded on Indian commodity futures market are cointegrated with their world counterparts. We reject the null hypothesis of rank $=0$ and can not reject the null hypothesis of rank $=1$ for all commodities under investigation at 5\% significance level. It is interesting to note that futures prices of agricultural commodities (Soybean and Corn) traded on India commodity futures exchanges are cointegarted with CBOT futures prices. Hua and Chen [38] investigated the similar relationship for Chinese commodity futures market and found the long run cointegration with world futures market for Aluminium, Copper and Soybean but did not find cointegration for Wheat futures traded on CBOT and the Chinese com- modity futures exchange.

\subsection{Weak Exogeneity Test}

The weak exogeneity test measures the speed of adjustment of prices towards the long run equilibrium relationship. If the two price series are cointegrated in longrun, then the coefficient matrix $\Pi$ (explained in Equation 1) can be decomposed as $\Pi=\alpha \beta^{\prime}$, where $\beta$ contains cointegrating vectors and $\alpha$ measures the average speed of adjustment towards the long-run equilibrium. The larger the value of $\alpha$, the faster is the response of prices towards the long-run equilibrium. If prices do not react to a shock or value of $\alpha$ is zero for that series, it is said to be weakly exogenous. We test the weak exogeneity of Indian commodity futures prices and world futures prices for each commodity. It is tested through likelihood-ratio test statistics with null hypothesis as $\alpha_{i}=0$. The results of this test are presented in Table 3.

The results of weak exogeneity test of Indian and the world commodity futures prices indicate that in most of the commodities, except Copper, Zinc and Natural gas, Indian commodity futures prices respond to any price discrepancies from long run equilibrium whereas the world futures prices are exogenous to the system. In case of Copper, both LME and Indian futures prices are ex- 
ogenous to the system. In case of Zinc and Natural gas, LME and NYMEX market respond to the error correcting terms to restore long run equilibrium whereas the Indian market is exogenous. Our results that the response of Indian commodity futures markets not to deviate too far from the long-run equilibrium relationship and the weak exogeneity of world prices for most of the commodities, indicate the leading role of world market in price discovery and satellite nature of Indian commodity futures markets.

\subsection{Short Run Cointegration}

After examining the long run integration between Indian and world markets, we also analyze the short-run integration or return spillover between these markets. The short run integration between Indian futures prices and their world counterparts is investigated through VECM model as these prices are cointegrated in the long run. The Granger causality test is also applied to examine the lead-lag relationship between Indian and the World counterpart. We apply forecast error variance decomposition for each returns series to understand the economic importance of one market on the other.

\section{Vector Error Correction Model (VECM)}

Since futures prices traded in Indian market and their

Table 2. Johansen cointegration test results.

\begin{tabular}{|c|c|c|c|c|c|c|}
\hline \multicolumn{2}{|c|}{ Commodity } & \multirow[t]{2}{*}{ Lag length } & \multicolumn{2}{|c|}{$\begin{array}{l}\text { Cointegration Rank Test Using } \\
\text { Maximum Eigenvalue }\end{array}$} & \multicolumn{2}{|c|}{ Cointegration Rank Test Using Trace } \\
\hline & & & $\begin{array}{c}\mathrm{H} 0: \text { rank }=0 \mathrm{Vs} \\
\mathrm{H} 1: \text { rank }=1\end{array}$ & $\begin{array}{c}\mathrm{H} 0: \mathrm{rank}=1 \mathrm{Vs} \\
\mathrm{H} 1: \mathrm{rank}=2\end{array}$ & $\begin{array}{c}\text { H0: rank }=0 \mathrm{Vs} \\
\text { H1: rank }=1\end{array}$ & $\begin{array}{c}\text { H0: } r a n k=1 \mathrm{Vs} \\
\text { H1: rank }=2\end{array}$ \\
\hline \multirow{2}{*}{ Agricultural } & Soy Bean & 3 & $31.7744 *$ & 2.4626 & $30.546^{*}$ & 2.1009 \\
\hline & Corn & 1 & $19.7004 *$ & 2.2961 & $21.0072 *$ & 2.507 \\
\hline \multirow{2}{*}{ Bullion } & Gold & 4 & $17.8351^{*}$ & 5.3996 & $23.4629 *$ & 4.9913 \\
\hline & Silver & 3 & $14.7067^{*}$ & 4.6723 & $19.379^{*}$ & 4.6723 \\
\hline \multirow{3}{*}{ Metals } & Aluminium & 5 & $24.4747^{*}$ & 3.8698 & $28.3445^{*}$ & 3.8698 \\
\hline & Copper & 4 & $13.1998^{*}$ & 4.9158 & $21.7399 *$ & 5.4253 \\
\hline & Zinc & 4 & $20.5895^{*}$ & 2.6857 & $29.6307^{*}$ & 2.5211 \\
\hline \multirow{2}{*}{ Energy } & Crude Oil & 3 & $17.586^{*}$ & 3.2128 & $23.2074 *$ & 3.5273 \\
\hline & Natural Gas & 3 & $22.6747 *$ & 2.7698 & $34.1376^{*}$ & 4.7614 \\
\hline
\end{tabular}

* denotes rejection of null at $5 \%$ level.

Table 3. Results of weak exogeneity test.

\begin{tabular}{|c|c|c|c|}
\hline & & World Prices & Indian Prices \\
\hline \multicolumn{2}{|c|}{ Commodity } & Chi-Square & Chi-Square \\
\hline \multirow[t]{2}{*}{ Agricultural } & Soy Bean & 0.87 & $27.65 * *$ \\
\hline & Maize & 0.1 & $17.13 * *$ \\
\hline \multirow[t]{2}{*}{ Bullion } & Gold & 0.78 & $3.87 *$ \\
\hline & Silver & 1.45 & $4.39 *$ \\
\hline \multirow[t]{3}{*}{ Metals } & Aluminium & 0.24 & $17.64 * *$ \\
\hline & Copper & 1.98 & 1.16 \\
\hline & Zinc & $4.03 *$ & 1.64 \\
\hline \multirow[t]{2}{*}{ Energy } & Crude Oil & 2.7 & $3.64 *$ \\
\hline & Natural Gas & $23.76^{* *}$ & 0.06 \\
\hline
\end{tabular}

** and * denote rejection of null at $1 \%(5 \%)$ level. 
world counterparts are cointegrated, short run relationship (return spillover) can be examined through error correction model. Vector error correction model specifications allow a long-run equilibrium error correction in prices in the conditional mean equations [46]. Similar approach has been used to model short run relationship of cointegrated variables [44-51]. The VECM specification for Indian futures prices and the world futures prices can be represented by

$$
\begin{aligned}
\Delta P_{W F, t}= & C_{W F}+\chi_{W F, E C} P_{W F, t-1}+\gamma_{I N, E C} P_{I N, t-1} \\
& +\sum_{i=2}^{k} \chi_{W F, i} \Delta P_{W F, t-i} \\
& +\sum_{j=2}^{l} \gamma_{I N, j} \Delta P_{I N, t-j}+\varepsilon_{W F, t} \\
\Delta P_{I N, t}= & C_{I N}+\chi_{I N, E C} P_{I N, t-1}+\gamma_{W F, E C} P_{W F, t-1} \\
& +\sum_{i=2}^{k} \chi_{I N, i} \Delta P_{I N, t-i} \\
& +\sum_{j=2}^{l} \gamma_{W F, j} \Delta P_{W F, t-j}+\varepsilon_{I N, t}
\end{aligned}
$$

Where, $P_{I N, t}$ is the log price in the Indian commodity futures market and $\mathrm{P}_{\mathrm{WF}, t}$ is the log futures prices in the World market. The error correction term $\chi_{I N, E C} P_{I N, t-1}+$ $\gamma_{W F, E C} P_{W F, t-1}$ or $\quad \chi_{W F, E C} P_{W F, t-1}+\gamma_{I N, E C} P_{I N, t-1} \quad\left(\Pi=\alpha \beta^{\prime}\right.$ representation) represents the speed of adjustment towards long run equilibrium. The short run parameter estimates $\chi_{I N}, \chi_{W F}, \gamma_{I N}$ and $\gamma_{W F}$ measure the short run integration or return spillover. The significance and value of these parameters measures the short run spillover between these markets. We performed the Granger causality test to find the lead-lag relationship between Indian commodity futures prices and the World counterparts. It tests whether, one endogenous variable (say $P_{I N, t}$ ) is significantly explained by other variable (say $P_{W F, t}$ ). More specifically, we say that $P_{W F, t}$ Granger causes $\mathrm{P}_{\mathrm{IN}, \mathrm{t}}$ if some of the $\gamma_{W F}(i)$ coefficients $(i=2,3, \cdots, p)$ are nonzero and/or $\gamma_{W F, E C}$ is significant at conventional levels. Similarly $P_{I N, t}$ Granger causes $P_{I N, t} \mathrm{t}$ if some of the $\gamma_{I N}(i)$ coefficients $(i=2, \cdots, p)$ are nonzero and/or $\gamma_{I N, E C}$ is significant at conventional levels.

Table 4 represents the results of VECM for Indian commodity futures prices and their world counterpart for all commodities. As mentioned earlier, we used Akaike Information Criterion (AIC) to select the lags in the VECM. We found that error correcting terms $\chi_{I N, E C} P_{I N, t-1}+\gamma_{W F, E C} P_{W F, t-1}$ in the equation of Indian futures prices are significant at $5 \%$ level for all commodities except Copper, Zinc and Natural gas. In case of Copper, error correcting term in the equation of the world futures returns are not significant. These terms are however significant only for Zinc and Natural gas. These findings are consistent with the results of weak exogeneity tests. It can be concluded that even though Indian futures market are cointegrated with the world futures prices for Copper, Zinc and Natural gas, in the short run Indian futures markets do not respond to the error correcting term. However, world prices (LME and NYMEX) returns respond to the error correcting term.

These results may be biased because of small sample size for Zinc and Natural gas contracts, as these have been traded only since August 2006 in Indian market. Further, it is not clear that whether results are due to frictions in the Indian commodity futures markets for these commodities, or dues to high transaction cost or the leading role of Indian markets in price discovery. This is beyond the scope of the paper and further research is required to address this issue. The short run coefficients $\gamma_{W F}(i)$, which measure the return spillover from world market to Indian futures market are also significant for Gold, Silver, crude, and Zinc. However, short run coefficients $\gamma_{I N}(i)$, which measures the return spillover from Indian market to the World markets, are significant only for metals. The results of the VECM indicate bi-directional causality between Indian market and their world counterparts for industrial metals. We estimated the Chi square statistics for Granger causality test to understand the lead-lag relationship between Indian commodity futures returns and their world counterpart. Results of the Granger causality test are reported in the Table $\mathbf{5}$.

The results of Granger causality test indicate that for Soybean, Corn, Gold, and Silver, world futures prices lead the Indian market and affect the Indian futures returns. The weak exogeneity test and results of error correction model also indicate the same for these commodeties. World futures price lead Indian markets in price discovery process and Indian market respond to long run as well as short run deviations in the prices. After combining the results of cointegration test and VECM model, it can be concluded that for Soybean, Corn, Gold, and Silver, the world markets affect Indian futures prices both in the long and short run.

In case of metals, we find bidirectional causality between MCX, India and LME, London for Aluminium futures prices. It is very surprising to note that in case of Copper and Zinc, Indian futures returns Granger cause (lead) the LME returns. These results could be due to the difference in the timing of closing hours and the effect of other important markets in the price discovery process. It is possible that a market, which closes after another market in the same underlying, is likely to impound more information from others markets, which are open at that time and the lead-lag relation, therefore, would be biased towards the market which closes later. In case of metals, Indian futures markets close after the LME and hence 
Table 4. Parameter estimates of VECM.

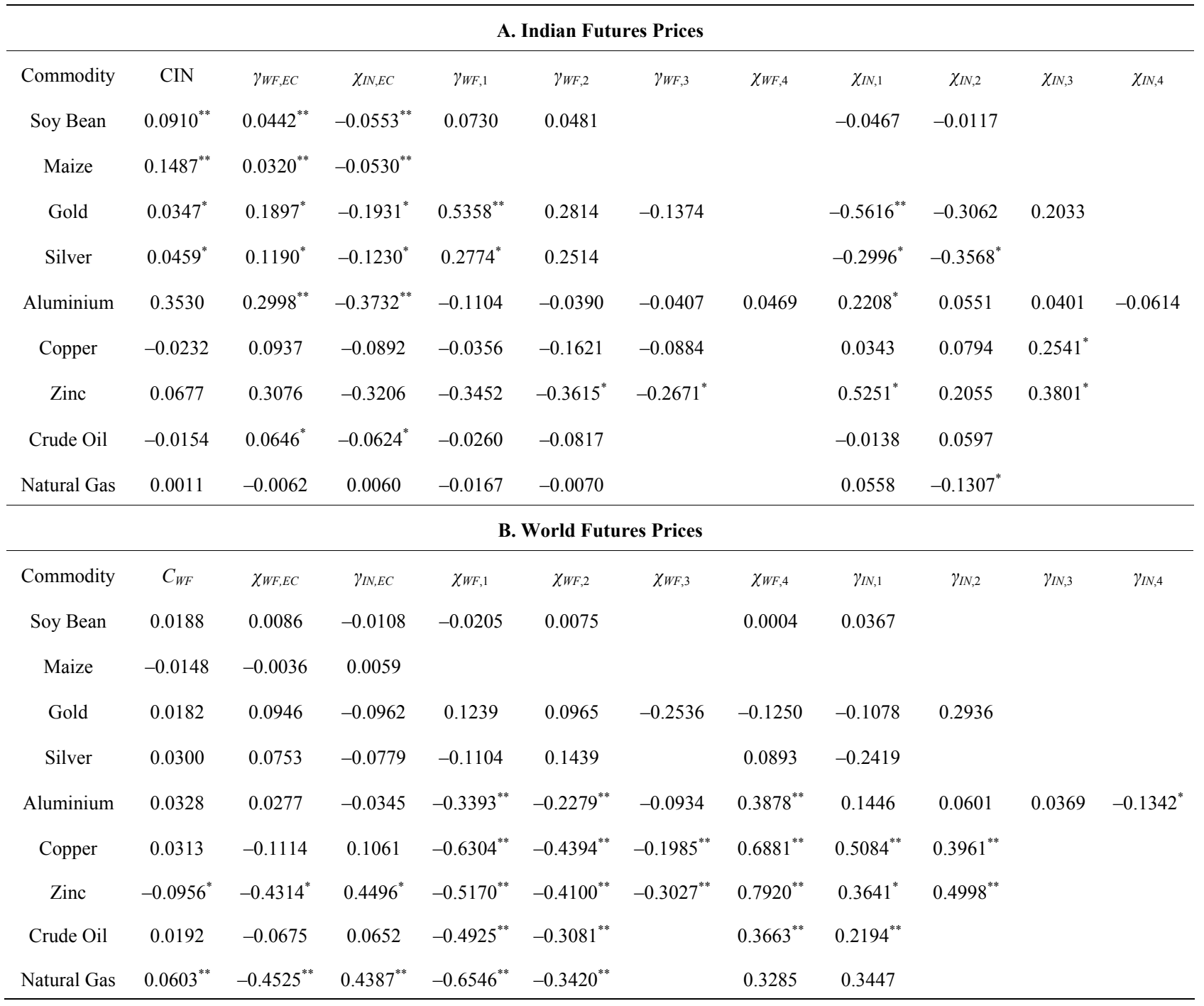

$* *$ and $*$ denote significance of parameter at $1 \%(5 \%)$ level.

Table 5. Results of granger causality test.

\begin{tabular}{cccc}
\hline & & International $\rightarrow$ India & India $\rightarrow$ International \\
\hline Agricultural & Soy Bean & $40.12^{* *}$ & 1.08 \\
& Maize & $16.36^{* *}$ & 0.06 \\
Bullion & Gold & $26.98^{* *}$ & 6.43 \\
& Silver & $14.02^{* *}$ & 5.53 \\
Aluminium & $21.6^{* *}$ & $51.24^{* *}$ & $117.79^{* *}$ \\
& Copper & 3.83 & $152.69^{* *}$ \\
Zinc & Crude Oil & 6.37 & $39.3^{* *}$ \\
& Natural Gas & 6.12 & $33.04^{* *}$ \\
\hline
\end{tabular}

\footnotetext{
** denotes rejection of null at $1 \%$ level.
} 
they may assimilate information from US markets, which are open at that time. Our result may be reflective of this fact $^{6}$. In case of energy commodities (Crude and Natural gas), results of Granger causality test indicate that Indian futures prices lead the NYMEX prices. This again is surprising.

Sims [52,53] and Abdullah and Rangazas [54] suggested that the variance decomposition of the forecast error is advisable while analyzing the dynamic relationship between variables because it may be misleading to rely solely on the statistical significance of economic variables as determined by VAR model or Granger causality test. Therefore, we also estimate the variance decomposition of the forecast error of each endogenous variable in order to further investigate the relationship between Indian and the world commodity futures markets.

\subsection{Variance Decomposition}

The variance decomposition of the forecast error gives the percentage of variation in each variable (e.g. Indian commodity futures returns) that is explained by the other variables (futures returns of markets elsewhere on the same underlying). We estimated the orthogonal variance decomposition of forecast error up to 20 lags from the VECM (Equation 4). Results of the variance decomposition for Indian commodity futures returns and their world counterparts are shown in Table 6. Panel-A of Table 6 explains the percentage of variation in futures price traded on world market explained by its own lagged returns and futures returns traded on Indian market whereas Panel-B of Table 6 represents the percentage of variation in Indian commodity futures returns explained by its own lagged returns and their world counterparts. As shown in Table 6, it is found that in the case of Soybean, Corn, Gold and Silver, variation in world futures returns are explained by their own lagged returns, whereas Indian futures returns explain $0 \%-1 \%$ variation in the futures returns of the market elsewhere.

On the other hand, in case of precious metals (Gold and Silver), variation in Indian futures returns are mostly explained by NYMEX returns (more than 90\%) and its own lagged returns explain only $10 \%$ variation. In case of agricultural commodities (Soybean and Corn), CBOT returns are able to explain more than 20\% [Soybean more than $20 \%$ and Corn more than $50 \%$ ] of variation in Indian futures returns. Results of agricultural commodeties and precious metals are consistent with the results of error correction model results and Granger causality test. In case of industrial metals, it is found that LME returns are able to explain more than $70 \%$ variation in Indian metals futures [Aluminium, Copper and Zinc $>70 \%$ ] whereas Indian returns are able to explain more than 5\% (Aluminium 5\% and Copper and Zinc 20\%) in LME metals futures returns. This result is not consistent with the results of Granger causality test especially results of Copper and Zinc where we find that Indian returns Granger cause LME returns. Thus, combining the evidence from both tests, it can be concluded that there may be bidirectional causality between Indian and LME return for metals but the effect of LME on the Indian prices is stronger than the effect of Indian prices on LME prices. In case of crude, NYMEX returns are mostly explained by their own lagged returns, however Indian futures re-

Table 6. Forecast error variance decompositions.

\begin{tabular}{|c|c|c|c|c|c|c|c|c|c|c|c|c|c|c|c|c|c|c|c|c|}
\hline & \multicolumn{10}{|c|}{ A. World Futures return explained by } & \multicolumn{10}{|c|}{ B. Indian Futures return explained by } \\
\hline & \multicolumn{5}{|c|}{ World Returns } & \multicolumn{5}{|c|}{ India Returns } & \multicolumn{5}{|c|}{ World Returns } & \multicolumn{5}{|c|}{ India Returns } \\
\hline & 1 & 5 & 10 & 15 & 20 & 1 & 5 & 10 & 15 & 20 & 1 & 5 & 10 & 15 & 20 & 1 & 5 & 10 & 15 & 20 \\
\hline Soy Bean & $100 \%$ & $100 \%$ & $100 \%$ & $100 \%$ & $100 \%$ & $0 \%$ & $0 \%$ & $0 \%$ & $1 \%$ & $1 \%$ & $1 \%$ & $4 \%$ & $11 \%$ & $19 \%$ & $28 \%$ & $99 \%$ & $96 \%$ & $89 \%$ & $81 \%$ & $72 \%$ \\
\hline Gold & $100 \%$ & $100 \%$ & $100 \%$ & $99 \%$ & $99 \%$ & $0 \%$ & $0 \%$ & $0 \%$ & $0 \%$ & $0 \%$ & $92 \%$ & $98 \%$ & $99 \%$ & $99 \%$ & $99 \%$ & $8 \%$ & $2 \%$ & $1 \%$ & $1 \%$ & $1 \%$ \\
\hline Silver & $100 \%$ & $100 \%$ & $99 \%$ & $98 \%$ & $98 \%$ & $0 \%$ & $0 \%$ & $0 \%$ & $0 \%$ & $0 \%$ & $89 \%$ & $96 \%$ & $98 \%$ & $99 \%$ & $99 \%$ & $11 \%$ & $4 \%$ & $2 \%$ & $1 \%$ & $1 \%$ \\
\hline Aluminium & $100 \%$ & $93 \%$ & $96 \%$ & $97 \%$ & $97 \%$ & $0 \%$ & $7 \%$ & $4 \%$ & $3 \%$ & $3 \%$ & $23 \%$ & $47 \%$ & $63 \%$ & $71 \%$ & $76 \%$ & $77 \%$ & $53 \%$ & $37 \%$ & $29 \%$ & $24 \%$ \\
\hline Copper & $100 \%$ & $80 \%$ & $79 \%$ & $80 \%$ & $80 \%$ & $0 \%$ & $20 \%$ & $21 \%$ & $20 \%$ & $20 \%$ & $59 \%$ & $60 \%$ & $64 \%$ & $68 \%$ & $70 \%$ & $41 \%$ & $40 \%$ & $36 \%$ & $32 \%$ & $30 \%$ \\
\hline Crude Oil & $100 \%$ & $92 \%$ & $91 \%$ & $90 \%$ & $89 \%$ & $0 \%$ & $8 \%$ & $9 \%$ & $10 \%$ & $11 \%$ & $6 \%$ & $4 \%$ & $4 \%$ & $4 \%$ & $4 \%$ & $94 \%$ & $96 \%$ & $96 \%$ & $96 \%$ & $96 \%$ \\
\hline Natural Gas & $100 \%$ & $90 \%$ & $78 \%$ & $69 \%$ & $60 \%$ & $0 \%$ & $10 \%$ & $22 \%$ & $31 \%$ & $40 \%$ & $45 \%$ & $49 \%$ & $55 \%$ & $60 \%$ & $64 \%$ & $55 \%$ & $51 \%$ & $45 \%$ & $40 \%$ & $36 \%$ \\
\hline
\end{tabular}

${ }^{6}$ We later analyze this issue by using trivariate VAR model in which other than MCX and LME prices, we include COMEX prices for industrial metals. 
turns are able to explain only $8 \%-10 \%$ variation in NYMEX returns. Further, NYMEX crude returns are able to explain only 4\% - 6\% variation in Indian returns. In case of Natural gas, Indian returns are able to explain 30\% $40 \%$ variation in NYMEX returns and NYMEX returns explains $50 \%-60 \%$ variation in Indian returns. We may conclude that in case of energy commodities bidirectional causality exist between MCX, India and NYMEX, US. However, effect of NYMEX market on Indian market is stronger than the effect of Indian market on NYMEX.

In order to shed more light into bidirectional causality between LME and MCX for industrial metals, we introduce a variable, COMEX, US, prices (Copper) ${ }^{7}$, in VECM model as another endogenous variable. As explained earlier, results of bivariate models with LME and MCX prices may be misleading because of extended trading period in Indian market and closing timing difference between LME and Indian market. The Indian market closes around two hours after the LME market and at that time COMEX market is trading. It is likely that the information is coming from COMEX market and is affecting LME market through MCX. Trading timings of LME, India and COMEX market are given in Table 7.

First, we test the cointegration ${ }^{8}$ between LME, MCX and COMEX Copper prices and it is found that these prices are cointegrated with single stochastic term, which indicates that the Copper prices are driven by a common factor. Results of Granger Causality test indicate that, LME prices are affected by both MCX and COMEX prices. We do not find any Granger causality between COMEX and MCX Copper futures prices. Results of Granger causality test of Copper is reported in Table 8.

We also estimate the variance decomposition from VECM (3), which explains the percentage of variation in each variable (e.g. LME copper futures returns) that is explained by other variables (COMEX copper futures returns and MCX copper futures returns) in the system. The results are shown in Table 9.

It is clear from the variance decomposition results that the LME returns' variance is mostly explained by its own lags $(65 \%)$ and COMEX returns (35\%). Indian market is not able to explain any variation in the LME returns or COMEX returns. It is also interesting to see that MCX Copper return variance is mostly explained by LME $(55 \%)$ return variance and COMEX return variance (38\%). It indicates that even in case of metals, Indian market gets information from world markets; LME and COMEX, and Indian market does not affect LME market. This negates the results of bivariate case wherein bidi-

\footnotetext{
${ }^{7}$ We are not able to get the data of other two industrial metals. However results of Copper can be extended to other industrial metals.

${ }^{8}$ Results of Cointegration and weak exogeneity test are not presented here and the same can be obtained from author on request.
}

rectional causality between LME and Indian futures prices is found. To sum up, it can be concluded that for all commodities, price discovery takes place in the world market and Indian futures market assimilate information through return spillover.

The VECM, Granger Causality test and variance decomposition examine the information transmission between markets by investigating first moment (mean return). However, the information transmission is better tested by examining the second moment or volatility spillover across markets. Ross [55] demonstrated that the rate of information transmission is critically linked to volatility.

\subsection{Volatility Spillover: A BEKK Model Approach}

After the seminal work of Engle, Ito and Lin [56], who applied multivariate GARCH model in estimating volatility spillover between US and Japanese foreign exchange markets, multivariate GARCH model has been widely applied to equity, exchange, bond and commodity markets etc. In this paper we apply multivariate GARCH model, BEKK (developed by Baba, Engle, Kraft and Kroner, 1991), to investigate volatility spillover between Indian commodity futures prices and their world counterpart. The residuals $-\varepsilon_{t}=\left(\varepsilon_{1 t}, \varepsilon_{2 t}\right)$ from VECM (Equation 4), which has conditional multivariate normal distribution the, are used in the following bivariate

Table 7. Trading timings of LME, India and COMEX exchanges.

\begin{tabular}{lccc}
\hline \multicolumn{3}{c}{ Exchange Timings } \\
\hline \multirow{4}{*}{ WME } & MCX & COMEX \\
\multirow{2}{*}{ Winter } & $17: 20$ p.m. - & $10: 00$ p.m.- & $18: 40$ p.m. - \\
& 22.30 p.m. & 23.55 p. m & 23.30 p.m. \\
Summer & $16: 20$ p.m. - & $10: 00$ p.m. - & $17: 40$ p.m. - \\
& $21: 30$ p.m. & 23.00 p. m & $22: 30$ p.m. \\
\hline
\end{tabular}

Table 8. Results of granger causality test of copper from VECM (3).

\begin{tabular}{ccc}
\hline Variables & Causality & Chi-Square \\
\hline \multirow{2}{*}{ LME and MCX } & LME $\rightarrow$ MCX & 1.61 \\
& MCX $\rightarrow$ LME & $43.53^{* *}$ \\
COMEX and MCX & COMEX $\rightarrow$ MCX & 4.33 \\
& MCX $\rightarrow$ COMEX & 2.95 \\
LME and COMEX & LME $\rightarrow$ COMEX & 4.56 \\
& COMEX $\rightarrow$ LME & $55.48^{* *}$ \\
\hline
\end{tabular}

** denotes rejection of null at $1 \%$ level. 
Table 9. Forecast error variance decompositions of copper returns from VECM (3).

\begin{tabular}{ccccccccccccccccc}
\hline & \multicolumn{4}{c}{ LME returns } & \multicolumn{1}{c}{ COMEX Return } & \multicolumn{4}{c}{ MCX returns } \\
\hline & 1 & 5 & 10 & 15 & 20 & 1 & 5 & 10 & 15 & 20 & 1 & 5 & 10 & 15 & 20 \\
LME returns & $100 \%$ & $79 \%$ & $70 \%$ & $65 \%$ & $63 \%$ & $0 \%$ & $21 \%$ & $29 \%$ & $33 \%$ & $36 \%$ & $0 \%$ & $1 \%$ & $1 \%$ & $1 \%$ & $1 \%$ \\
COMEX Return & $63 \%$ & $59 \%$ & $59 \%$ & $58 \%$ & $58 \%$ & $37 \%$ & $41 \%$ & $41 \%$ & $41 \%$ & $42 \%$ & $0 \%$ & $0 \%$ & $0 \%$ & $0 \%$ & $0 \%$ \\
MCX returns & $69 \%$ & $60 \%$ & $56 \%$ & $53 \%$ & $52 \%$ & $23 \%$ & $33 \%$ & $38 \%$ & $40 \%$ & $41 \%$ & $8 \%$ & $7 \%$ & $7 \%$ & $7 \%$ & $7 \%$ \\
\hline
\end{tabular}

$\operatorname{BEKK}(p, q)$ model.

The $\operatorname{BEKK}(\mathrm{p}, \mathrm{q})$ representation of the variance of error term $H_{t}$

$$
H_{t}=C_{0}^{\prime} C_{0}+\sum_{i=1}^{q} A^{\prime} \varepsilon_{t-i} \varepsilon_{t-i}^{\prime} A_{i}+\sum_{i=1}^{p} G_{i}^{\prime} H_{t-i} G_{i}
$$

Where, $A_{i}$ and $G_{i}$ are $k \times k$ parameter matrix and $\mathrm{C}_{0}$ is $k \times$ $k$ upper trangular matrix. Bivariate $\operatorname{VAR}(\mathrm{k}) \operatorname{BEKK}(1,1)$ model can be written as

$$
\begin{aligned}
& =C_{0}^{\prime} C+\left[\begin{array}{ll}
a_{11} & a_{12} \\
a_{21} & a_{22}
\end{array}\right]^{\prime}\left[\begin{array}{cc}
\varepsilon_{1, t-1}^{2} & \varepsilon_{2, t-1} \varepsilon_{1, t-1} \\
\varepsilon_{2, t-1} \varepsilon_{1, t-1} & \varepsilon_{2, t-1}^{2}
\end{array}\right] \\
& \times\left[\begin{array}{ll}
a_{11} & a_{12} \\
a_{21} & a_{22}
\end{array}\right]+\left[\begin{array}{ll}
g_{11} & g_{12} \\
g_{21} & g_{22}
\end{array}\right]^{\prime} H_{T-1}\left[\begin{array}{ll}
g_{11} & g_{12} \\
g_{21} & g_{22}
\end{array}\right]
\end{aligned}
$$

Or simply,

$$
\begin{aligned}
& H_{t} h_{11}=c_{1}+a_{11}^{2} \varepsilon_{1, t-1}^{2}+2 a_{11} a_{21} \varepsilon_{1, t-1} \varepsilon_{2, t-1}+a_{21}^{2} \varepsilon_{2, t-1}^{2} \\
& +g_{11}^{2} h_{11, t-1}^{2}+2 g_{11} g_{21} h_{12, t-1}+g^{2}{ }_{21} h_{22, t-1}^{2} \\
& h_{12}=c_{2}+a_{11} a_{12} \varepsilon_{1, t-1}^{2}+\left(a_{21} a_{12}+a_{11} a_{22}\right) \varepsilon_{1, t-1} \varepsilon_{2, t-1} \\
& +a_{21} a_{22} \varepsilon_{2, t-1}^{2}+g_{11} g_{12} h_{11, t-1} \\
& +\left(g_{21} g_{12}+g_{11} g_{22}\right) h_{12, t-1}+g_{21} g_{22} h_{22, t-1} \\
& h_{22}=c_{3}+a_{12}^{2} \varepsilon_{1, t-1}^{2}+2 a_{12} a_{22} \varepsilon_{1, t-1} \varepsilon_{2, t-1} \\
& +a_{22}^{2} \varepsilon_{2, t-1}^{2}+g_{12}^{2} h_{11, t-1}^{2}+2 g_{12} g_{22} h_{12, t-1}+g_{22}^{2} h_{22, t-1}
\end{aligned}
$$

In the BEKK representation of volatility, the parameter, $a_{21}$ is the volatility spillover from market 2 to market 1 , and $a_{12}$ indicates the spillover from market 1 to market 2. Hence, the statistical significance of these parameters tells about the volatility spillover between markets. In the BEKK representation, we assume a conditional time invariant covariance, namely constant conditional correlation (CCC) assumption between futures returns traded in Indian market and futures prices traded outside India.

Tse [57] explained that the two-step approach of first estimating the residuals from VECM (Equation 4) and then estimating bivatiate BEKK models (Equation 7), is efficient and equivalent to joint estimation of the two steps. The two step estimation method also reduces the problem of estimating large number of parameters in- volved in the process. Following Engel and $\mathrm{Ng}$ [58], Kroner and $\mathrm{Ng}$ [59], Tse [57], so Tse [60] and Kao and Wang [40], we perform the two step estimation process to investigate the volatility spillover between Indian and their world counterparts for each of the nine commodities.

We estimated the parameters of $\operatorname{BEKK}(1,1)$ for each commodity separately. Parameters estimate are presented in Table 10. As explained in Equation 7, $h_{11}$ estimates the conditional volatility of world futures and the parameter $a_{21}$ is the volatility spillover from India to the world futures market. Similarly $\mathrm{h}_{22}$ estimates the conditional volatility of Indian commodity futures and the parameter $a_{12}$ measures the volatility spillover from the world market to India. These two parameters measure the volatility spillover between Indian futures market and markets abroad.

In case of agricultural commodities, it is found that the volatility of futures returns traded in India and CBOT is highly autoregressive. It is interesting to note that for Soybean, volatility spills over from Indian market to CBOT. The parameter is significant at 5\% level. Also, for Corn, bidirectional volatility spillover is found. The parameters $a_{21}$ and $a_{12}$ are significant at $1 \%$ signifycant level. As explained earlier, the results of VECM model indicate that $\mathrm{CBOT}$ market play a leading role in price discovery for Soybean and Corn. However, results of volatility spillover indicate that Indian futures market also affect the CBOT futures market.

In case of precious metals, we find bidirectional volatility spillover between Indian market and NYMEX for Gold only. In Silver market, there is no significant volatileity spillover between the markets. The volatility spillover between Indian futures market and LME is investigated for Aluminium, Copper and Zinc. In case of Aluminium, both parameters $a_{21}$ and $a_{12}$ are insignificant, for Copper both parameters $a_{21}$ and $a_{12}$ are significant at 5\% significant level and for Zinc only $a_{12}$ is significant at $1 \%$ significant level. These results indicate that there is significant information spillover from LME market to India through volatility for Copper and Zinc. Indian market affects LME volatility for Copper only. The BEKK results of energy commodities indicate that volatility spillover is mainly taking place from NYMEX 
Table 10. Parameters estimates of BEKK $(1,1)$ model.

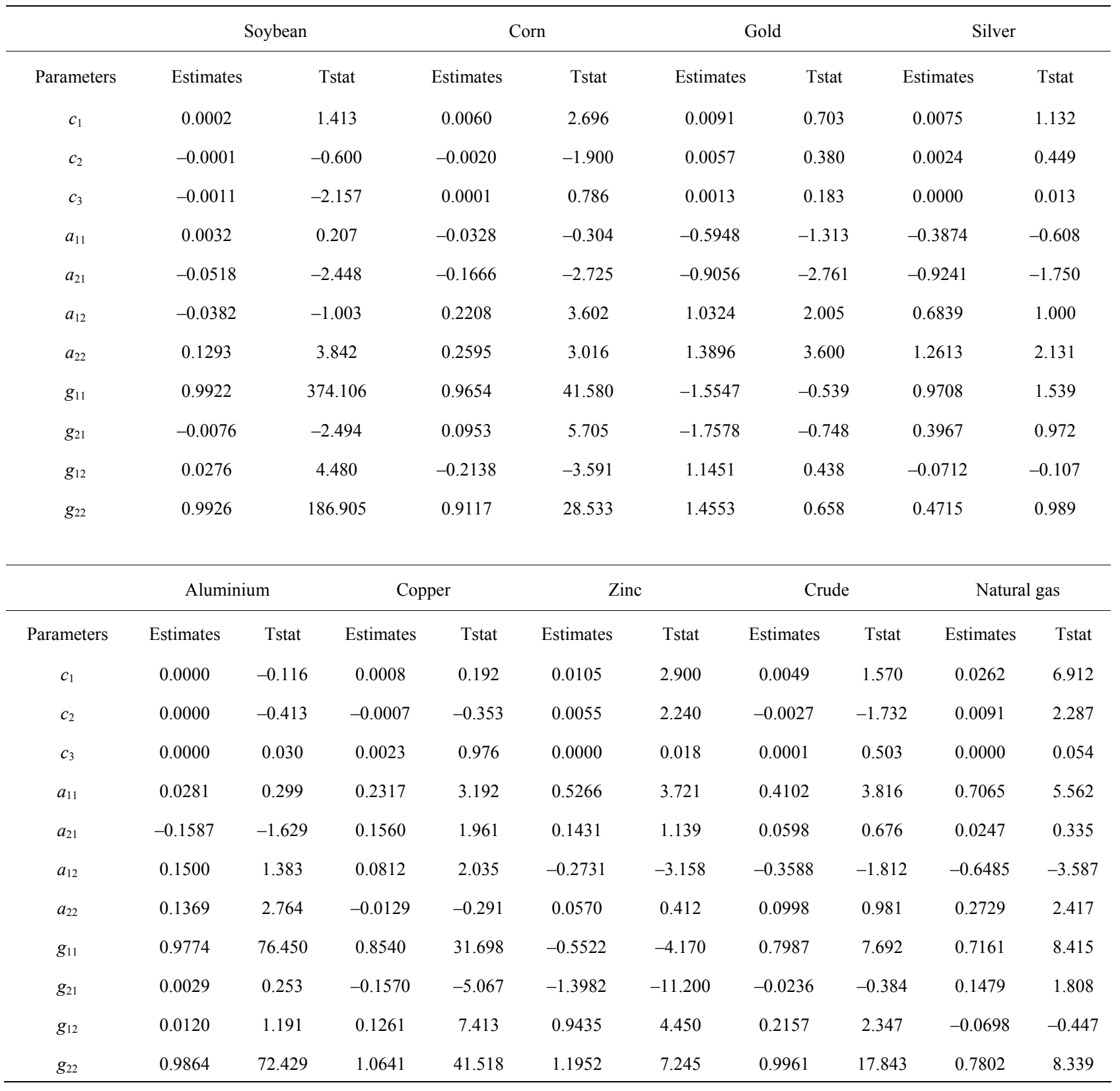

futures market to Indian market; $a_{12}$ parameter is significant at $10 \%$ and $1 \%$ significance level for crude and Natural gas respectively.

\section{Conclusions}

Since the inception of modern electronic trading platform, combined with establishment of three national commodity exchanges, India has become one of the fastest growing commodity futures markets in the world. Like other emerging markets, Indian commodity futures are of recent origin, suggesting that Indian markets may respond to global markets. On the contrary, it can be argued that, given the size of the economy, Indian market may also influence global markets. This issue has interesting implications to gain insight on the directionality of information generation and assimilation in the commodities markets. The purpose of the study reported in this paper is to investigate the relationship between Indian commodity futures with their world counterparts.

The results of long run relationship between Indian futures prices and their world counterparts indicate that for all the nine commodities studied, the Indian markets are cointegrated with the world markets. The weak exo- 
geneity test indicates that for most of the commodities Indian futures prices adjust to any discrepancy from long run equilibrium whereas the world prices are exogenous to the system. The Granger Causality test results and variance decomposition of forecast error of VECM model indicate that there exists one-way causality from world markets to Indian market in most of the commodities. The impact of CBOT on Indian agricultural futures market is unidirectional and approximately 30\% - 40\% variations in returns of Indian commodity futures are explained by CBOT futures prices. In case of precious metals, NYMEX market unidirectionally affects Indian futures prices and it explains around $98-99 \%$ variation in Indian futures returns. In case of industrial metals also, we find unidirectional information spillover through returns. For industrial metals, Indian market is extensively influenced by LME and other developed markets with LME having stronger impact on Indian prices while Indian market having no impact on LME or other futures markets. For energy commodities, Brent crude oil and Natural gas, both Indian and NYMEX market influence each other but, NYMEX has stronger impact on Indian prices. However, in case of energy commodities, the effect of world prices is not as strong as in case of precious metals and industrial metals. This may be because of higher governmental control (tariff barriers/subsidy) in crude oil and natural gas or because of difference in inventory and transportation costs.

Volatility spillover analysis indicates similar results, but it is interesting to note that for agricultural commodities, volatility spillover also takes place from Indian futures to CBOT futures. Bidirectional volatility spillover between Indian and NYMEX is also observed for Gold futures. In case of industrial metal futures, volatility spills from LME to Indian market except for Copper futures whereas Indian market also affects LME futures. In case of Crude oil and Natural gas, unidirectional volatility spillover from NYMEX futures to Indian futures is found. To sum up, we find the US market plays an important leading role in information transmission to the Indian market for Soybean, Corn, Gold, Silver, Crude and Natural gas and LME leads the indian markets for industrial metals. Overall, we also find that the Indian futures markets are cointegrated with the world markets and are working as a satellite market. They are able to assimilate information through return and volatility spillovers from world markets.

\section{References}

[1] H. Working, "New Concepts Concerning Futures Markets and Prices," American Economic Review, Vol. 52, 1962.

[2] W. Silber, "Innovation, Competition, and New Contract
Design in Futures Markets," Journal of Futures Markets, 21981

[3] I. G. Kawaller, P. Koch and T. Koch, "The Temporal Price Relationship between S\&P 500 Futures and the S\&P 500 Index," Journal of Finance, Vol. 42, No. 5, 1987, pp. 1309-1329. doi:10.2307/2328529

[4] H. R. Stoll and R. E. Whaley, "The Dynamics of Stock Index and Stock Index Futures Returns," Journal of Financial and Quantitative Analysis, Vol. 25, No.4, 1990, pp. 441-468. doi:10.2307/2331010

[5] J. A. Stephan and R. E. Whaley, "Intraday Price Change and Trading Volume Relations in the Stock and Stock Option Markets," Journal of Finance, Vol. 45, No. 1, 1990, pp. 191-220. doi:10.2307/2328816

[6] K. Chan, "A Further Analysis of the Lead-Lag Relationship between the Cash Market and Stock Index Futures Market," Review of Financial Studies, Vol. 5, No. 1, 1992, pp. 123-152. doi:10.1093/rfs/5.1.123

[7] M. A. Pizzi, A. J. Economopoulos and H. M. O’Neil, “An Examination of the Relationship between Stock Index Cash and Futures Markets: A Cointegration Approach," The Journal of Futures Markets, Vol. 18, No. 3, 1998, pp. 297-305.

doi:10.1002/(SICI)1096-9934(199805)18:3<297::AID-F UT4>3.0.CO;2-3

[8] G. G. Booth and C. Ciner, "International Trans-Mission of Information in Corn Futures Markets," Journal of Multinational Financial Management, Vol. 7, No. 3, 1997, pp. 175-187. doi:10.1016/S1042-444X(97)00012-1

[9] F. Pattarin and R. Ferretti, "The Mib30 Index and Futures Relationship: Economic Analysis and Implications for Hedging," Applied Financial Economics, Vol. 14, No. 18, 2004, pp. 1281-1289. doi:10.1080/09603100412331313578

[10] H.-J. Ryoo and G. Smith, "The Impact of Stock Index Futures on the Korean Stock Market," Applied Financial Economics, Vol. 14, No. 4, 2004, pp. 243-251. doi:10.1080/0960310042000201183

[11] D. G. MacMillan, "Cointegrating Behaviour between Spot and forward Exchange Rates," Applied Financial Economics, Vol. 15, No. 6, 2005, pp. 1135-1144. doi:10.1080/09603100500359476

[12] T. Fortenbery and H. Zapata, "An Evaluation of Price Linkages between Futures and Cash Markets for Cheddar Cheese," Journal of Futures Markets, Vol. 17, No. 3, 1997, pp. 279-301. doi:10.1002/(SICI)1096-9934(199705)17:3<279::AID-F UT2>3.0.CO;2-F

[13] P. Silvapulle and I. Moosa, "The Relationahip between Spot and Futures Prices: Evidence from the Crude Oil Market," Journal of Futures Markets, Vol. 19, No. 2, 1999, pp. 175-193.

doi:10.1002/(SICI)1096-9934(199904)19:2<175::AID-F UT3>3.0.CO;2-H

[14] I. Moosa, "Price Discovery and Risk Transfer in the Crude Oil Futures Market: Some Structural Time Series Evidence," Economic Notes by Banca Monte dei Paschi di Siena SpA 31, 2002, pp. 155-165. 
[15] I. Figuerola-Ferretti and C. Gilbert, "Price Discovery in the Aluminium Market," Journal of Futures Markets, Vol. 25, No. 10, 2005, pp. 967-988. doi:10.1002/fut.20173

[16] J. Yang, R. B. Balyeat and D. J. Leatham, "Futures Trading Activity and Commodity Cash Price Volatility," Journal of Business Finance and Accounting, Vol. 32, No. 1-2, 2005, pp. 297-323. doi:10.1111/j.0306-686X.2005.00595.x

[17] K. N. Kabra, "Commodity Futures in India," Economic and Political Weekly, March 31, 2007, pp. 1163-1170.

[18] B. P. Pashigian, "The Political Economy of Futures Market Regulation," Journal of Business, Vol. 59, No. 2, 1986, pp. 55-84. doi:10.1086/296339

[19] R. D. Weaver nd A. Banerjee, "Does Futures Trading Destabilize Cash Prices? Evidence for US Live Beef Cattle," Journal of Futures Markets, Vol. 10, No. 1, 1990, pp. 41-60. doi:10.1002/fut.3990100105

[20] S. Thomas, "Agricultural Commodity Markets in India: Policy Issues for Growth," Mimeo, Indira Gandhi Institute for Development Research, Mumbai, India, 2003.

[21] D. S. Kolamkar, "Regulation and Policy Issues for Commodity Derivatives in India," 2003.

http://www.igidr.ac.in/ susant/DERBOOK/PAPERS/dsk _draft1.pdf, Accessed on 20, January, 2009.

[22] C. K. G. Nair, "Commodity Futures Markets in India: Ready for "Take-Off”?" NSE News, July, 2004.

[23] S. Thomas and K. Karande, "Price Discovery across Multiple Spot and Futures Markets," 2002. http://www.igidr.ac.in/ susant/PDFDOCS/ThomasKaran de2001 pricediscovery castor.pdf

[24] K. G. Sahadevan, "Sagging Agricultural Commodity Exchanges: Growth Constraints and Revival Policy Options," Economic and Political Weekly, Vol. 37, No. 30, 2002, pp. 3153-3160.

http://www.jstor.org/stable/4412417

[25] G. Naik and S. K. Jain, "Indian Agricultural Commodity Futures Markets: A Performance Survey," Economic and Political Weekly, Vol. 37, No. 30, 2002, pp. 3161-3173.

http://www.jstor.org/stable/4412418

[26] A. Roy and B. Kumar, "A Comprehensive Assessment of Wheat Futures Market: Myths and Reality," Paper presented at International Conference on Agribusiness and Food Industry in Developing Countries: Opportunities and Challenges, held at IIM Lucknow, August 10-12, 2007.

[27] C. S. Eun and S. Shim, "International Transmission of Stock Market Movements," Journal of Financial and Quantitative Analysis, Vol. 24, No. 2, 1989, pp. 241-256. doi: $10.2307 / 2330774$

[28] M. King and S. Wadhwani, "Transmission of Volatility between Stock Markets," Review of Financial Studies, Vol. 3, No. 1, 1990, pp. 5-33. doi:10.1093/rfs/3.1.5

[29] R. Susmel and R. F. Engle, "Hourly Volatility spill overs between international equity markets," Journal of International Money and Finance, Vol. 13, No. 1, 1994, pp. 325. doi:10.1016/0261-5606(94)90021-3
[30] G. Koutmos and G. G.Booth, "Asymmetric Volatility Transmission in International Stock Markets," Journal of International Money and Finance, Vol. 14, No. 6, 1995, pp. 747-762. doi:10.1016/0261-5606(95)00031-3

[31] G. G.Booth, T. H. Lee and Y. Tse, "International Linkages in the Nikkei Stock Index Futures Markets," Pacific Basin Finance Journal, Vol. 4, No. 1, 1996, pp. 59-76. doi:10.1016/0927-538X(95)00023-E

[32] G. G. Booth, P. Brockman and Y. Tse, "The Relationship between US and Canadian Wheat Futures," Applied Financial Economics, Vol. 8, No. 1, 1998, pp. 73-80. doi:10.1080/096031098333276

[33] Y. Tse, "International Linkages in Euromark Futures Markets: Information Transmission and Market Integration," Journal of Futures Markets, Vol. 18, No. 2, 1998, pp. 129-149. doi:10.1002/(SICI)1096-9934(199804)18:2<129::AID-F UT1>3.0.CO;2-K

[34] H. G.Fung, W. K.Leung and X. E. Xu, "Information Role of US Futures Trading in a Global Financial Market," Journal of Futures Markets, Vol. 21, No. 11, 2001, pp. 1071-1090. doi:10.1002/fut.2105

[35] G. G. Booth and C. Ciner, "International Trans-Mission of Information in Corn Futures Markets," Journal of Multinational Financial Management, Vol. 7, No. 3, 1997, pp. 175-187. doi:10.1016/S1042-444X(97)00012-1

[36] A. H. W. Low, J. Muthuswamy and R. I. Webb, "Arbitrage, Cointegration, and the Joint Dynamics of Prices across Commodity Futures Auctions," The Journal of Futures Markets, Vol. 19, No. 7, 1999, pp. 799-815. doi:10.1002/(SICI)1096-9934(199910)19:7<799::AID-F $\mathrm{UT} 4>3.0 . \mathrm{CO} ; 2-5$

[37] S. X. Lin and M. M. Tamvakis, "Spillover Effects in Energy Futures Markets," Energy Economics, Vol. 23, No. 1, 2001, pp. 43-56. doi:10.1016/S0140-9883(00)00051-7

[38] M. E. Holder, R. D. Pace and M. J. Tomas III, "Complements or Substitutes? Equivalent Futures Contract Markets - the Case of Corn and Soybean Futures on US and Japanese Exchanges," The Journal of Futures Markets, Vol. 22, No. 4, 2002, pp. 355-370. doi:10.1002/fut.10009

[39] X. E. Xu, , H. G. Fung, "Cross-Market Linkages between US and Japanese Precious Metals Futures Trading," International Finance Markets, Institution and Money, Vol. 15 , No. 2, 2005, pp. 107-124. doi:10.1016/j.intfin.2004.03.002

[40] C. W. Kao and J. Y. Wan, "Information Transmission and Market Interactions across the Atlantic-an Empirical Study on the Natural Gas Market," Energy Economics, Vol. 31, No. 1, 2009, pp. 152-161. doi:10.1016/j.eneco.2008.07.007

[41] H. G. Fung, W. K. Leung and X. E. Xu, "Information Flows between the US and China Commodity Futures Trading," Review of Quantitative Finance and Accounting, Vol. 21, No. 3, 2003, pp. 267-285. doi:10.1023/A:1027384330827

[42] R. Hua and B. Chen, "International Linkages of the Chi- 
nese Futures Markets," Applied Financial Economics, Vol. 17, No. 6, 2007, pp. 1275-1287. doi:10.1080/09603100600735302

[43] Y.Ge, H. H. Wang and S. K. Ahn, "Implication of Cotton Price Behavior on Market Integration," Proceedings of the NCCC-134 Conference on Applied Commodity Price Analysis, Forecasting, and Market Risk Management, St. Louis, 2008.

http://www.farmdoc.illinois.edu/nccc134/conf_2008/pdf/ confp22-08.pdf

[44] W. G. Tomek, "Price Behavior on a Declining Terminal market," American Journal of Agricultural Economics, Vol. 62, No. 3, 1980, pp. 434-445. doi:10.2307/1240198

[45] C. A. Carter, "Arbitrage Opportunities between Thin and Liquid Futures Markets," The Journal of Futures Markets, Vol. 9, No. 4, 1989, pp. 347-353. doi:10.1002/fut.3990090408

[46] R. F. Engle and C. W. J. Granger, "Co-integration and Error Correction: Representation, Estimation and Testing," Econometrica, Vol. 55, No. 2, 1987, pp. 251-276. doi: $10.2307 / 1913236$

[47] S. Johansen, "Estimation and Hypothesis Testing of Cointegration Vectors in Gaussian Vector Autoregressive Models," Econometrica, Vol. 59, No. 6, 1991, pp. 15511580. doi: $10.2307 / 2938278$

[48] S. Johansen and K. Juselius, "Maximum Likelihood Estimation and Inference on Cointegration with Applications to the Demand for Money," Oxford Bulletin of Economics and Statistics, Vol. 52, No. 2, 1990, pp. 169-210. doi:10.1111/j.1468-0084.1990.mp52002003.x

Ghosh, Saidi and Johnson, 1999

[49] F. H. Harris, T. H. McInish, G. L. Shoesmith and R. A. Wood, "Cointegration, Error Correction, and Price Discovery on Informationally Linked Security Markets," Journal of Financial and Quantitative Analysis, Vol. 30, No. 4, 1995, pp. 563-579. doi:10.2307/2331277

[50] Y. W. Cheung and. H. G. Fung, "Information Flows between Eurodollar Spot and Futures Markets," Multinational Finance Journal, Vol. 1, No.4, 1997, pp. 255-271.
[51] A. Ghosh, R. Saidi and K. H. Johnson, "Who Moves the Asia-Pacific Stock Markets-US or Japan? Empirical Evidence Based on the Theory of Cointegration," Financial Review, Vol. 34, No. 1, 1999, pp. 159-170. doi:10.1111/j.1540-6288.1999.tb00450.x

[52] C. Sims, "Money, Income, and Causality," American Economic Review, Vol. 62, 1972, pp. 540-552.

[53] C. Sims, "Macroeconomics and Reality," Econometrica, Vol. 48, No. 1, 1980, pp. 1-48. doi:10.2307/1912017

[54] D. A. Abdullah and P.C. Rangazas, "Money and the Business Cycle: Another Look," Review of Economics and Statistics, Vol. 70, No. 4, 1988, pp. 680-685. doi:10.2307/1935833

[55] S. A. Ross, "Information and Volatility: The No-Arbitrage Martingale Approach to Timing and Resolution Irrelevancy," Journal of Finance, Vol. 44, No. 1, 1989, pp. 1-17. doi: $10.2307 / 2328272$

[56] R. F. Engle, T. Ito and W. L. Lin, "Metero Showers or Heat Waves? Heteroskedastic Intra-Daily Volatility in the Foreign Exchange Market," Econometric, Vol. 58, No. 3, 1990, pp. 525-542 . doi:10.2307/2938189

[57] Y. Tse, "Price Discovery and Volatility Spillovers in the DJIA Index and Futures Market," Journal of Futures markets, Vol. 19, No. 8, 1999, pp. 911-930. doi:10.1002/(SICI)1096-9934(199912)19:8<911::AID-F UT4>3.0.CO;2-Q

[58] R. F. Engle and V. K. Ng, "Time-Varying Volatility and the Dynamic Behavior of the Term Structure," Journal of Money, Credit and Banking, Vol. 25, No. 3, 1993, pp. 336-349. doi: $10.2307 / 2077766$

[59] K. F. Kroner and V. K. Ng, "Modeling Asymmetric Comovements of Asset Returns," Review of Financial Studies, Vol. 11, No. 4, 1998, pp. 817-844. doi:10.1093/rfs/11.4.817

[60] R. W. So and Y. Tse, "Price Discovery in the Hang Seng Index Markets: Index, Futures, and the Tracker Fund," Journal of Futures Markets, Vol. 24, No. 9. 2004, pp. 887-907. doi:10.1002/fut.20112 